\title{
Antimicrobial activity and bioautographic study of antistaphylococcal components from Caesalpinia pyramidalis Tull.
}

\author{
Antonio Marcos Saraiva ${ }^{1 *}$, Cristiane Lopes Saraiva ${ }^{1}$, Admário Marques Gonçalves ${ }^{1}$, \\ Rogério Ribeiro Soares ${ }^{1}$, Fabrício de Oliveira Mendes ${ }^{1}$, Risonildo Pereira Cordeiro', \\ Haroudo Satiro Xavier², Maria Nelly Caetano Pisciottano ${ }^{1}$
}

\author{
${ }^{1}$ Microbiological Analysis Laboratory, Pharmaceutical Science Department, Federal University of Pernambuco, \\ ${ }^{2}$ Pharmacognosy Laboratory, Pharmaceutical Science Department, Federal University of Pernambuco
}

\begin{abstract}
The antimicrobial activity of dry methanol and ethyl acetate extracts for the leaves, bark of the stem, peel of the root, flower, fruit and seed of Caesalpinia pyramidalis Tull. (catingueira) was performed against seventeen isolates of Staphylococcus aureus MRSA multiresistant strains, which included two isolates of $S$. aureus MSSA and two ATCC strains. The antimicrobial activity was tested by the agar diffusion method and the Minimum Inhibitory Concentration (MIC) was determined. The dry methanol extract of the root showed good antimicrobial activity with a MIC of less than $0.5 \mathrm{mg} \cdot \mathrm{mL}^{-1}$. The dry ethyl acetate extracts exhibited lower antimicrobial activity, which might be explained by solubility problems and less diffusion in the agar medium. Results of the bioautographies also confirmed inhibition halos corresponding to the active substances present in the leaves, as well as in the flower of C. pyramidalis. The phytochemical study of the leaves, bark of the stem, peel of the root, flower and fruit of extracts from $C$. pyramidalis confirmed the presence of a number of known antimicrobial agents including ursolic acid, quercetin, catechin, ellagic acid, sitosterol, flavonoids, proanthocyanidins and gallic acid.
\end{abstract}

Uniterms: Caesalpinia pyramidalis/antimicrobial activity. Caesalpinia pyramidalis/bioautographic study. Caesalpinia pyramidalis/antistaphylococcal components. Staphylococcus aureus/multiresistant. Brazilian Epidemic Clone.

\begin{abstract}
A determinação da atividade antimicrobiana dos extratos metanólicos e em acetato de etila da folha, casca do caule, casca da raiz, flor, fruto e semente de Caesalpinia pyramidalis Tull. foi realizada frente a dezessete isolados de Staphylococcus aureus MRSA multirresistentes, dois isolados de $S$. aureus MSSA e duas cepas padrão, pelas técnicas de poço/difusão em ágar e determinação das CMI pelo método de diluição em agar/multiinoculador de Stears. O extrato metanólico de casca da raiz indicou uma boa atividade, com CMI inferior a $0.5 \mathrm{mg} \cdot \mathrm{mL}^{-1}$. Os extratos secos por extração em acetato de etila apresentaram menor atividade que se poderia explicar por problemas de solubilidade e menor difusão no meio de cultura em ágar. Resultados das bioautografias confirmaram zonas de inibição correspondente às substâncias ativas presente na folha, como também na flor da C. pyramidalis. No estudo fitoquímico das folhas, casca da caule, casca da raiz, flor e fruto dos extratos de $C$. pyramidalis evidenciou-se a presença de vários constituintes com reconhecida atividade antimicrobiana, entre estes o ácido ursólico, quercetina, catequina, ácido elágico, sitosterol, flavonóides, proantocianidinas e ácido gálico. Entre todos os metabólitos citados, somente o ultimo não observamos, por CCD, na casca da raiz de C. pyramidalis.
\end{abstract}

Unitermos: Caesalpinia pyramidalis/atividade antimicrobiana. Caesalpinia pyramidalis/estudo bioautográfico. Caesalpinia pyramidalis/componentes antiestafilocócicos. Staphylococcus aureus/ multirresistente. Clone Epidêmico Brasileiro.

\footnotetext{
*Correspondence: A. M. Saraiva. Laboratório de Análises Microbiológicos, Departamento de Ciências Farmacêuticas, Universidade Federal de Pernambuco 50740-521 - Recife - PE, Brazil. E-mail: saraivas2@yahoo.com.br
} 


\section{INTRODUCTION}

The importance of nosocomial infection caused by Staphylococcus aureus, especially by methicillin resistant $S$. aureus (MRSA) is well known for its frequency, morbidity, mortality and principally for its difficulty to treat (Nascimento et al., 2000). The strains of MRSA are resistant to all $\beta$-lactamics, macrolides, tetracycline, aminoglycosides, while the two glycopeptides (vancomycin and teicoplanin) remain the only alternatives for clinical treatment against infections of MRSA multiresistant $S$. aureus (Shibata et al., 2005). However, S. aureus with intermediate susceptibility to vancomycin (VISA) or $S$. aureus glycopeptides (GISA) has recently been identified in different countries. Subsequently, strains of $S$. aureus resistant to vancomycin (VRSA) have also emerged, possessing a different mechanism to those of VISA strains (Nishi et al., 2004).

Studies conducted in Brazil have described a clone of methicillin resistant Staphylococcus aureus (Brazilian Epidemic Clone-BEC, ST247-SCCmecIIIA) that is disseminated and predominates within hospitals throughout the country. It was also observed that this clone has spread to other countries in South America (Argentine, Chile, Colombia, Peru, Ecuador, Uruguay), besides Europe (Portugal, Italy and the Czech Republic) and Asia (Miranda et al., 2007; Sola et al., 2002; Rodríguez-Noriega et al., 2010). In light of this evidence, the need to identify new antimicrobial agents is clear.

Caesalpinia pyramidalis Tull., Leguminous family (Fabaceae) is a tree found in the Northeastern region of Brazil, popularly known as "catingueira", "pau-de-porco" and "mussitaiba". In folk medicine, its flowers, seeds, leaves and bark of the stem are used for the treatment of catarrhal infections, diarrheas and dysentery, besides being endowed with antipyretic and diuretic properties (Mendes et al., 2000; Braga, 1960; Rêgo Júnior et al., 2011).

A large number of metabolites have been isolated from 'catingueira', such as: phenylpropanoids, lupeol, $\beta$-sitosterol, bioflavonoids (agastiflavone, amentoflavone, sequoiaflavone and podocarpusflavone), chalcone, kaempferol, apigenin, lignane, stigamasterol and methyl gallate (Mendes et al., 2000; Bahia et al., 2010; Novais et al., 2003). Crude ethyl acetate from the leaves and roots of $C$. pyramidalis Tull. tested against strains of $S$. aureus and Escherichia coli by the agar disc diffusion method showed inhibition halos in the order of $10 \mathrm{~mm}$ for the $S$. aureus strains.

\section{MATERIAL AND METHOD}

\section{Collection and identification}

The plant was collected in the town of Carnaubeira da Penha, in the hinterland of Pernambuco (State), at a latitude of $08^{\circ} 19^{\prime} 09^{\prime \prime}$, longitude of $38^{\circ} 44^{\prime} 41^{\prime \prime}$ and altitude of 446 meters (MME, 2005), between the months of March and June, 2004. Samples were identified by employees of the Herbarium of the Empresa Pernambucana de Pesquisa Agropecuária (IPA), Dr. Rita de Cássia Pereira, and deposited with voucher $n^{\circ} 70.008$.

\section{Preparation of extracts}

For determination of the antibacterial activity of C. pyramidalis, different fresh material parts of the plant including leaves, bark of the stem, peel of the root, flower, seeds and fruit were triturated, weighed and submitted to three successive extractions by the process of infusion, with medium intervals of 72 hours for each solvent. The order of solvents used was $n$-hexane, followed by ethylic acetate and lastly methanol. The extracts thus obtained were filtered and solvents evaporated at $40{ }^{\circ} \mathrm{C}$ under reduced pressure. These were subsequently weighed and their output calculated.

The dry extracts obtained from the methanol extraction were reintroduced into water/DMSO $(1: 1 \mathrm{v} / \mathrm{v})$ (Sakagami et al., 2005) at a concentration of $100 \mathrm{mg} \cdot \mathrm{mL}^{-1}$. The dry extracts obtained from the ethyl acetate and n-hexane extractions were also reintroduced in tween 80 /water (4.8:0.2 v/v) at a concentration of $100 \mathrm{mg} \mathrm{mL}^{-1}$.

\section{Bacteria strains}

A total of twenty-one Staphylococcus aureus strains, comprising nineteen clinical isolates and two standard strains, were used in the study (Table I). These consisted of eight multiresistant $S$. aureus MRSA of the Brazilian epidemic clone (BEC), five isolates of the pediatric epidemic clone, four isolates of the sporadic clones and two MSSA strains which were only resistant to the antibiotics penicillin, erythromycin and gentamycin. The multiresistant $S$. aureus MRSA and $S$. aureus MSSA were strains from the Microbiological Analysis Laboratory collection, derived from a study on the susceptibility/resistance profile of $S$. aureus in Recife-Pernambuco state (Cordeiro, 2004).

\section{Preparation of inoculates}

The inoculates were prepared starting with the $24 \mathrm{~h}$ 
TABLE I - List of Staphylococcus aureus strains assayed

\begin{tabular}{llcl}
\hline Reg. N & Profile & Clone & Origin \\
\hline AM723 & MRSA & A1 & Catheter point \\
AM793 & MRSA & A1 & Tracheal secretion \\
AM799 & MRSA & A5 & Vesical probe point \\
AM837 & MRSA & A7 & Catheter point \\
AM858 & MRSA & A13 & Catheter point \\
AM895 & MRSA & A6 & Hemoculture \\
AM902 & MRSA & A2 & Orifice secretion \\
AM948 & MRSA & A9 & Catheter point \\
AM599 & MRSA & B3 & Ulcer Secretion \\
AM642 & MRSA & B5 & Secretion \\
AM771 & MRSA & B2 & Tracheal secretion \\
AM922 & MRSA & B6 & Left leg wound \\
AM942 & MRSA & B4 & Hemoculture \\
AM594 & MRSA & F & Catheter point \\
AM872 & MRSA & G & Urine \\
AM875 & MRSA & D & Hemoculture \\
AM876 & MRSA & I & Hemoculture \\
AM632 & MSSA & - & Operation wound \\
AM672 & MSSA & - & Tracheal secretion \\
AM103 & - & - & ATCC 6538 \\
AM106 & - & - & ATCC 6538P \\
\hline
\end{tabular}

Reg. $\mathbf{N}^{\mathbf{0}}$ : Register Number; AM: Microbiological analysis laboratory collection - Pharmaceutical Science Department -UFPE; ATCC: American type culture collection; Clone A: Brazilian epidemic clone (BEC); Clone I, D, G, F: Sporadic clone; Clone B: Pediatric clone; MRSA: Methicillin resistant Staphylococcus aureus; MSSA: Methicillin sensitive Staphylococcus aureus

colonies culture of $S$. aureus in Mueller-Hinton agar and suspended in sterile physiological solute, comparing the turbidity with the 0.5 tube of the McFarland scale $\left(10^{8} \mathrm{UFC} \mathrm{mL}^{-1}\right)$ (CLSI, 2003).

\section{Agar well diffusion method}

The inoculum were applied to the surface of the Mueller-Hinton agar and after perforation of the wells (perforator $6 \mathrm{~mm}$ in diameter), $100 \mu \mathrm{L}$ of the extracts (concentrations of $100 \mathrm{mg} \cdot \mathrm{mL}^{-1}$ and $50 \mathrm{mg} \mathrm{mL}^{-1}$ ), standard antibiotic $\left(300 \mu \mathrm{g} \mathrm{mL}^{-1}\right)$ and of the control solution (DMSO at $50 \%(\mathrm{v} / \mathrm{v})$ or tween 80 at $4 \%(\mathrm{v} / \mathrm{v}))$ were added to each well. After incubation at $37^{\circ} \mathrm{C} \pm 1$ for 24 hours, the diameter of the inhibition halos were measured and results evaluated according to the following scale: inhibition halos of $9 \mathrm{~mm}$ - inactive; 9-12 $\mathrm{mm}$ - somewhat active; 13$18 \mathrm{~mm}$ - active; $18 \mathrm{~mm}$ - very active (Alves et al., 2000).

\section{Agar dilution method - Determination of Minimum Inhibitory Concentration (MIC)}

The minimum inhibitory concentration for the extracts (basic solution of $20 \mathrm{mg} \cdot \mathrm{mL}^{-1}$ ), dilutions in water with concentrations of $312.5 \mu \mathrm{g} \cdot \mathrm{mL}^{-1}$ to $20.10^{3} \mu \mathrm{g} \cdot \mathrm{mL}^{-1}$, had been prepared and incorporated to Mueller-Hinton agar (1:9), thus final concentrations of $31.5 \mu \mathrm{g} . \mathrm{mL}^{-1}$ to $2000 \mu \mathrm{g} . \mathrm{mL}^{-1}$ of the extracts remained. The standard antibiotics used were tetracycline and oxacillin (Sigma), with concentrations as indicated by the CLSI (2003) norms.

The twenty-one inoculates were distributed aseptically in the Stears multi-inoculator, and then deposited on the surface of the culture medium, and incubated at $36^{\circ} \mathrm{C}$ \pm for 24 hours.

Duplicate controls were performed at the beginning and end of the inoculation control process. Control of the diluents was also done (tween 80 at $4 \%$ and DMSO at $50 \%)$

The results were interpreted comparatively to the strain controls and determined by the first plate whose concentration inhibited growth.

\section{Phytochemical analysis}

Thin layer chromatography (TLC) with silica-gel $\mathrm{GF}^{\circ} 254$ (Merck) was used. The methanol or ethyl acetate extracts of the leaves and flower of Caesalpinia pyramidalis at the concentration of $20 \mathrm{mg} \mathrm{mL}^{-1}$ were applied using an analytic capillary $(15 \mu \mathrm{L})$. The mobile phase for the methanol extracts was the chromatographic system (1): $\mathrm{AcOEt} / \mathrm{MeOH} / \mathrm{H} 2 \mathrm{O}$ (81:11:08), while for the corresponding ethyl acetate the system (2): $\mathrm{AcOEt} / \mathrm{HCOOH} / \mathrm{AcOH} /$ $\mathrm{H}_{2} \mathrm{O}$ (100:2:2:2 and 100:3:3:3) was employed. TLC was performed in duplicate, one being used as a chromatographic reference and the other for bioautography.

In the phytochemical study, standards of gallic acid, ellagic acid, quercetin, kaempferol, catechin, ursolic acid, $\beta$-sitosterol, $\beta$-amyrin, pilocarpine, iridoids, and glucose were used.

The visualization of TLC was carried out under UV light (254 and $366 \mathrm{~nm}$ ), as shown in Table II.

\section{Bioautographic technique}

The developed TLC according to system (1) was subjected to aseptic current air for 5 minutes, and another developed by system (2) for $6 \mathrm{~h}$, respectively. On the TLC 
TABLE II - Chromatographic systems used for phytochemical screening of Caesalpinia pyramidalis Tull.

\begin{tabular}{|c|c|c|c|}
\hline Metabolites & Elution System & Revelator & Reference \\
\hline Alkaloids & $\mathrm{A}$ & Dragendorff & Wagner et al., 1984 \\
\hline Triterpenoids and Esteroids & B & Liebermann-Burchard & Harbone, 1998 \\
\hline Iridoids & A & Sulfuric Vanilin & Wagner et al., 1984 \\
\hline Saponins & A & Anisaldehyde & Wagner and Bladt, 1996 \\
\hline Sugars & $\mathrm{C}$ & TTC & Metz, 1961 \\
\hline Coumarins & $\mathrm{D}$ & U.V & Wagner, Bladt, 1996 \\
\hline Cinnamic Derivatives & A & NEU & Wagner, Bladt, 1996 \\
\hline Flavonoid & A & NEU & $\begin{array}{l}\text { Wagner et al., } 1984 \\
\text { Markham, } 1982\end{array}$ \\
\hline Phenylpropane glycosides & $\mathrm{A}$ & NEU & Wagner, Bladt, 1996 \\
\hline $\begin{array}{l}\text { Condensed Proanthocyanidine } \\
\text { and Leucoanthocyanidines }\end{array}$ & A & Chloridric Vanillin & Robertson et al., 1957 \\
\hline
\end{tabular}

A: EtOAc-HCOOH-AcOH-H2O (100:11:11:26 v/v); B: EtOAc-HCOOH-AcOH-H2O (100:0.5:0.5:0.5 v/v); C: n-BuOH-Me ${ }_{2} \mathrm{CO}-$ Buffer Phosphate $\mathrm{pH}=5.0$ (40:50:10 v/v); D: Et ${ }_{2} \mathrm{O}$-toluene-AcOH 10\% (50:50:50 v/v); NEU: 2-Amino-ethyl-diphenyl borinate, TTC: Triphenyl Tetrazolium Chloride.

surface, melted Mueller-Hinton agar (MH) was added, inoculated with a saline suspension of $S$. aureus ATCC 6538 (bacterial suspension at $10^{8} \mathrm{UFC} / \mathrm{mL}$ ) and homogeneously distributed over the TLC plate. After solidification of inoculated $\mathrm{MH}$, it was left for 30 minutes at the surrounding ambient temperature of $25^{\circ} \mathrm{C}$ for predifusion of the active components. Subsequently, it was incubated for 24 to 36 hours $\pm 1{ }^{\circ} \mathrm{C}$. After this period the bioautography was revealed with a solution of 2,3,5-triphenyltetrazolium chloride (TTC) at $2.5 \mathrm{mg} \mathrm{mL}^{-1}$ and incubated for a further 4 hours.

The presence of an inhibition zone indicated the existence of active components (Pessini et al., 2003).

\section{RESULTS AND DISCUSSION}

\section{Antimicrobial activity}

The results of methanol and ethyl acetate extracts from $C$. pyramidalis against four clinical isolates and one standard strain (AM103) of $S$. aureus are given in Table III. The hexane extracts showed no activity. The diameters of the inhibition halos expressed in millimeters are expressed in the form of a table for each extract and each bacterium.

The MIC values of the assayed extracts are shown separately, according to type of $S$. aureus MRSA multiresistant clone. Table IV summarizes the results of eight Brazilian epidemic clones, five pediatric clones, four sporadic multiresistant clones, two strains of $S$. aureus MSSA, and finally two standard strains.
TABLE III - Antimicrobial activity of Caesalpinia pyramidalis against $S$. aureus

\begin{tabular}{|c|c|c|c|c|c|c|}
\hline \multirow{2}{*}{ Extracts } & \multirow{2}{*}{$\mathrm{mg} /$ Well } & \multicolumn{5}{|c|}{ S. aureus (AM) halo diameter in $\mathrm{mm}$} \\
\hline & & 594 & 723 & 922 & 942 & 103 \\
\hline \multirow[t]{2}{*}{$\mathbf{L M}$} & $10 \mathrm{mg}$ & 18 & 20 & 20 & 21 & 20 \\
\hline & $5 \mathrm{mg}$ & 15 & 15 & 16 & 18 & 16 \\
\hline \multirow[t]{2}{*}{ BM } & $10 \mathrm{mg}$ & 20 & 18 & 18 & 19 & 21 \\
\hline & $5 \mathrm{mg}$ & 17 & 15 & 16 & 16 & 19 \\
\hline \multirow[t]{2}{*}{ RM } & $10 \mathrm{mg}$ & 19 & 16 & 17 & 17 & 20 \\
\hline & $5 \mathrm{mg}$ & 19 & 16 & 17 & 17 & 20 \\
\hline \multirow[t]{2}{*}{ FLM } & $10 \mathrm{mg}$ & 20 & 22 & 22 & 22 & 23 \\
\hline & $5 \mathrm{mg}$ & 17 & 18 & 18 & 19 & 21 \\
\hline \multirow[t]{2}{*}{ FM } & $10 \mathrm{mg}$ & 20 & 20 & 19 & 21 & 23 \\
\hline & $5 \mathrm{mg}$ & 18 & 18 & 16 & 19 & 20 \\
\hline \multirow[t]{2}{*}{ SM } & $10 \mathrm{mg}$ & 17 & 16 & 19 & 17 & 20 \\
\hline & $5 \mathrm{mg}$ & 15 & 14 & 16 & 16 & 18 \\
\hline \multirow[t]{2}{*}{ LA } & $10 \mathrm{mg}$ & - & - & - & - & 12 \\
\hline & $5 \mathrm{mg}$ & - & - & - & - & - \\
\hline \multirow[t]{2}{*}{$\mathbf{B A}$} & $10 \mathrm{mg}$ & 16 & 15 & 15 & 16 & 18 \\
\hline & $5 \mathrm{mg}$ & 14 & 13 & 12 & 12 & 14 \\
\hline \multirow[t]{2}{*}{ RA } & $10 \mathrm{mg}$ & 18 & 18 & 20 & 19 & 20 \\
\hline & $5 \mathrm{mg}$ & 16 & 17 & 16 & 17 & 18 \\
\hline \multirow[t]{2}{*}{ FA } & $10 \mathrm{mg}$ & 14 & 13 & 12 & 18 & 18 \\
\hline & $5 \mathrm{mg}$ & 12 & - & - & 15 & - \\
\hline TT & $30 \mathrm{mcg}$ & 11 & 12 & 27 & 12 & 28 \\
\hline
\end{tabular}

L: (leaves); FL (flower); B (bark of stem); R (peel of root); F (fruit); S (seeds); M (methanol); A (ethyl acetate) TT: Tetracycline; AM: Microbiological analysis laboratory collection - Pharmaceutical Science Department -UFPE 


\section{Bioautography}

The bioautographic results for the leaves and flower extracted in methanol and ethyl acetate, and peel of the root extracted in ethyl acetate, from C. pyramidalis are listed in Table V.

\section{Phytochemical study}

The secondary metabolites found in the extracts of the parts studied from C. pyramidalis with well-known antimicrobial activity are shown in Table VI.

Among the two techniques used for the determina-

TABLE IV - Minimum Inhibitory Concentration (MIC) of extracts from Caesalpinia pyramidalis against Staphylococcus aureus strains

\begin{tabular}{|c|c|c|c|c|c|c|c|c|c|c|c|c|c|c|}
\hline \multirow{2}{*}{\multicolumn{2}{|c|}{ STRAINS }} & \multicolumn{9}{|c|}{ MIC of extracts from Caesalpinia pyramidalis $\left(\mathrm{mg} \mathrm{mL}^{-1}\right)$} & \multicolumn{2}{|c|}{$\begin{array}{l}\text { MIC of Antibiotics } \\
\qquad\left(\mathrm{mg} \mathrm{mL}^{-1}\right)\end{array}$} & \multicolumn{2}{|c|}{ Antibiotics } \\
\hline & & LM & $\mathrm{BM}$ & RM & FLM & $\mathrm{FM}$ & SM & RA & FA & BA & Tet & Oxa & Sensitive & Resistant \\
\hline AM & 723 & 1 & 1 & 1 & 2 & $>2$ & $>2$ & 2 & $>2$ & 2 & 0.032 & 0.064 & 1 & $2,3,4,5,6,7,8$ \\
\hline AM & 793 & 1 & 1 & 0.5 & 0.5 & 1 & 1 & 0.25 & 1 & $>2$ & $>0.064$ & 0.256 & 1 & $2,3,4,5,6,7,8$ \\
\hline AM & 799 & 1 & 1 & 0.5 & 0.5 & 2 & 1 & 0.25 & 0.5 & $>2$ & 0.064 & 0.256 & 1 & $2,3,4,5,6,7,8$ \\
\hline AM & 837 & 2 & 2 & 1 & 1 & NT & NT & NT & NT & 2 & 0.032 & 0.256 & 1 & $2,3,4,5,6,7,8$ \\
\hline AM & 858 & 1 & 1 & 0.25 & 1 & NT & NT & NT & NT & $>2$ & 0.032 & 0.256 & 1 & $2,3,4,5,6,7,8$ \\
\hline AM & 895 & 1 & 1 & 0.5 & 1 & 2 & 1 & 0.25 & 1 & NT & 0.064 & 0.064 & 1 & $2,3,4,5,6,7,8$ \\
\hline AM & 902 & $>2$ & $>2$ & 1 & 2 & NT & NT & NT & NT & 2 & $>0.064$ & 0.032 & 1 & $2,3,4,5,6,7,8$ \\
\hline AM & 948 & NT & NT & 0.5 & 0.5 & 2 & $>2$ & 1 & 0.5 & 2 & 0.064 & 0.256 & 1 & $2,3,4,5,6,7,8$ \\
\hline $\mathbf{A M}$ & 599 & 2 & $>2$ & 1 & 1 & 2 & 2 & NT & 1 & $>2$ & 0.001 & 0.016 & $1,2,4,7,5$ & $3,6,8$ \\
\hline AM & 642 & 2 & 2 & 1 & 1 & 2 & 1 & $>2$ & 2 & $>2$ & 0.0005 & 0.032 & $1,7,5,4$ & $3,2,6,8$ \\
\hline AM & 771 & 2 & 1 & 0.5 & 0.5 & $>2$ & 1 & NT & 0.5 & 2 & 0.0005 & 0.032 & $1,2,4,7,5$ & $3,6,8$ \\
\hline AM & 922 & $>2$ & 1 & 1 & 1 & 1 & 2 & 2 & 1 & 2 & 0.002 & 0.064 & $1,2,3,4,7$ & $6,8,5$ \\
\hline AM & 942 & 1 & 0.5 & 1 & 1 & 1 & $>2$ & NT & 2 & 2 & 0.032 & 0.016 & $1,2,3,5,7$ & $4,6,8$ \\
\hline $\mathbf{A M}$ & 594 & 0.5 & 1 & 1 & 1 & 2 & 2 & $>2$ & 0.125 & 1 & 0.032 & 0.256 & 1 & $3,4,6,2,7,5,8$ \\
\hline $\mathbf{A M}$ & 872 & $>2$ & 1 & 1 & 2 & $>2$ & $>2$ & NT & 0.125 & $>2$ & 0.016 & 0.128 & $1,2,3,5,7$ & $4,6,8$ \\
\hline AM & 875 & 2 & 2 & 0.5 & 1 & 2 & 2 & NT & 0.5 & 2 & 0.0005 & 0.016 & $1,2,4,7,5$ & $3,6,8$ \\
\hline AM & 876 & 2 & 2 & 0.5 & 0.5 & 2 & 1 & $>2$ & 0.5 & 2 & 0.002 & 0.032 & $1,2,3,4,7,5$ & 6,8 \\
\hline AM & 632 & 2 & 2 & 1 & 1 & 2 & 1 & 2 & 1 & $>2$ & 0.001 & 0.00013 & $1,2,6,4,7,5$ & 3,8 \\
\hline AM & 672 & 2 & 2 & NT & NT & $>2$ & 1 & 2 & 0.5 & $>2$ & 0.001 & 0.00013 & $1,2,3,4,6,7$ & 5,8 \\
\hline AM & 103 & 2 & 2 & 0.5 & 0.5 & 2 & 1 & 2 & 0.25 & 2 & 0.00025 & 0.00006 & ATCC 6538 & \\
\hline $\mathbf{A M}$ & 106 & 2 & 1 & 0.5 & 1 & 2 & 0.5 & $>2$ & 0.25 & 2 & 0.00025 & 0.00013 & ATCC 6538P & \\
\hline
\end{tabular}

NT: Not tested; L: (leaves); FL (flower); B (bark of stem); R (peel of root); $\mathbf{F}$ (fruit); S (seeds); M (methanol); $\mathbf{A}$ (ethyl acetate); (1) - vancomycin; (2) - ciprofloxacin; (3) - erythromycin; (4) -tetracycline (Tet); (5) - gentamicin; (6) - oxacillin (Oxa); (7) - sulfamethoxazole/trimethoprim;

(8) - penicillin.; AM: Microbiological analysis laboratory collection - Pharmaceutical Science Department-UFPE

TABLE V - Retention factor values related to inhibition halos of extracts of Caesalpinia pyramidalis obtained by bioautographic technique

\begin{tabular}{lccccc}
\hline Chromatograph Systems & Extracts & \multicolumn{5}{c}{ Retention Factor $(\mathrm{R} f s)$} \\
\hline AcOEt $/ \mathrm{MeOH} / \mathrm{H}_{2} \mathrm{O}(81: 11: 08)$ & LM & 0.55 & 0.84 & 0.94 \\
& FLM & 0.19 & 0.29 & 0.48 & 0.94 \\
$\mathrm{AcOEt} / \mathrm{HCOOH} / \mathrm{AcOH} / \mathrm{H}_{2} \mathrm{O}(100: 2: 2: 2$ and $100: 3: 3: 3)$ & LA & 0.51 & 0.62 & 0.80 & 0.68 \\
& FLA & 0.62 & & & 0.58 \\
\hline
\end{tabular}

L: (leaves); FL (Flower); R (Peel of Root); M (Methanol); A (Ethyl Acetate); AcOEt: Ethyl acetate, MeOH: Methanol, HCOOH:

Formic Acid, AcOH: Acetic Acid. 
TABLE VI - Secondary metabolites from Caesalpinia pyramidalis with well-known antimicrobial activity

\begin{tabular}{lccccc}
\hline \multirow{2}{*}{ Secondary Metabolites } & \multicolumn{5}{c}{ Caesalpinia pyramidalis } \\
\cline { 2 - 6 } & Leaves & Stem of Bark & Peel of Root & Fruit & Flower \\
\hline Ursolic Acid & $(-)$ & $(-)$ & + & $(-)$ & $(-)$ \\
Sitosterol & + & + & + & + & + \\
Cinnamic Derivatives & + & + & + & + & + \\
Flavanoids of Aglicones & + & + & + & + & + \\
Quercetin & $(-)$ & $(-)$ & + & $(-)$ & $(-)$ \\
Condensed Proanthocyanidins & $(-)$ & + & + & $(-)$ & $(-)$ \\
Catechin & $(-)$ & + & + & $(-)$ & $(-)$ \\
Gallic Acid & $(-)$ & $(-)$ & $(-)$ & + & + \\
Ellagic Acid & $(-)$ & $(-)$ & + & + & + \\
\hline
\end{tabular}

+: Metabolite Present; (-): Metabolite Absent

tion of antimicrobial activity, the agar well diffusion technique, despite using larger volumes $(100 \mu \mathrm{L})$ (Caetano et al., 2002) compared to disks $(10 \mu \mathrm{L})$ (Voravuthikunchai and Kitppipit, 2005), has the advantage of allowing the use of adjuvant to improve the solubility of the extract constituents and to permit radial as well as superficial diffusions, conditions resulting in better inhibition halos.

With regard to the five Staphylococcus aureus strains studied, four represent the three types of MRSA multiresistant clones and one the standard strain.

In Table III, the extract of the flower methanol (FLM) showed the largest inhibition halos for the five tested strains, with values in the order of $22 \mathrm{~mm}$, at the highest concentration (10 $\mathrm{mg} /$ well), corresponding to the very active classification (Alves et al., 2000), and halos in the order of $16 \mathrm{~mm}$ for concentrations of $5 \mathrm{mg}$ per well, with extracts of leaves, peel of the root, fruit and seed also having good activity.

In general, extracts from retrieval in ethyl acetate showed smaller inhibition halos compared with those extracted from methanol. This fact can be due to the polarity characteristics of its constituents which resulted in lower diffusion in aqueous environs and therefore produced smaller inhibition halos despite having substances with antimicrobial activity (Lenette et al., 1987).

Observing Table III of the corresponding extracts (leaves, bark of the stem, peel of the root, fruit and seed) in ethyl acetate, the extract of peel of the root produced inhibition halos in the order of $20 \mathrm{~mm}$, while the extract of the leaves showed no activity except against the standard strain (AM103). Experimentally, this difference may be explained by the fact that the dry extract of peel of the root is in the form of powder and dissolved very well in tween 80 /water $4 \%$ whereas extract from the leaves had a pasty consistency and was not well dissolved, hindering its solubility.

The inhibition zone produced by the standard antibiotic, tetracycline, confirmed the resistance phenotype of the clone strains, i.e. Staphylococcus aureus MRSA AM594, S. aureus AM723 and S. aureus AM942, resistant to tetracycline had inhibition halos in the order of $13 \mathrm{~mm}$ or less while the strains $S$. aureus MRSA AM922 and $S$. aureus AM103 sensitive to tetracycline had inhibition halos in the order of $26 \mathrm{~mm}$.

Finally, the two diluents, DMSO at $50 \%$ and tween 80 at $4 \%$, exhibited no inhibition.

The presented data are mean values of two determinations.

On the other hand, the presence of active substances in the leaves as well as in the flower for both types of extracts was evidenced in the results of the bioautographies (Table V).

The bioautography technique permits the detection of inhibition halos that reveal the presence of active substances in the TLC (Pessini et al., 2003) against $S$. aureus ATCC 6538 in the methanolic extracts, one in $\mathrm{R} f 0.48$ for the flower extract and $\mathrm{R} f 0.55$ for the leaves extract. Similarly, for the extracts in ethyl acetate, one showed the presence of inhibition halos in $\mathrm{R} f 0.62$ for the flower extract, the $\mathrm{R} f 0.51, \mathrm{R} f 0.62, \mathrm{R} f 0.80$ and $\mathrm{R} f 0.94$ for the leaves extract and the $\mathrm{R} f 0.26, \mathrm{R} f 0.39, \mathrm{R} f 0.58, \mathrm{R} f 0.68$, , $\mathrm{R} f 0.77$ and $\mathrm{R} f 0.92$ for the stem bark extract (Table $\mathrm{V}$ ).

The phytochemical investigation evidenced the presence of substances such as flavonoids (flavonoid aglycones), sitosterol and cinnamic derivatives for all the extracts of $C$. pyramidalis tested. The presence of gallic acid and ellagic acid was also evidenced in the flower extract in methanol. Other components identified were 
polyphenols (phenolic acid) in the fruit, and ursolic acid and quercetin from the bark of the stem and peel of the root (root and bark of the stem) thus confirming data from the literature (Bahia et al., 2010; Bahia et al., 2005).

With reference to MIC (Table IV), analysis of the results reveals that, in the case of $S$. aureus MRSA Brazilian epidemic clone, that some of the values are less than 0.5 $\mathrm{mg} \cdot \mathrm{mL}^{-1}$ for the methanol extracts as well as ethyl acetate extracts of the peel of the root.

Similar results were found for the methanol extract of the flower.

The MIC values for the five pediatric clones were again low for the extracts of the peel of the root, being in the order of $0.25 \mathrm{mg} . \mathrm{mL}^{-1}$ for both methanol and ethyl acetate extracts.

Also, in Table IV featuring MIC for the four sporadic clones together with the susceptible $S$. aureus MSSA strains and standard strains, the extracts of the peel of the root in ethyl acetate had some values as low as $0.125 \mathrm{mg} \mathrm{mL}^{-1}$, even less than those of the MSSA strains $\left(0.5 \mathrm{mg} \mathrm{mL}^{-1}\right)$ and standard strains $\left(0.25 \mathrm{mg} \mathrm{mL}^{-1}\right)$.

The MIC values of tetracycline and oxacillin confirmed the phenotype resistance and MRSA or MSSA character of isolates of $S$. aureus strains, respectively.

In relation to the DMSO diluents at $50 \%$ and tween 80 at $4 \%$, these showed no inhibition against any of the twenty-one strains, confirming earlier data for DMSO by Sakagami et al. (2005).

\section{CONCLUSION}

The extracts from C. pyramidalis showed good antimicrobial activity against the $\mathrm{S}$. aureus multiresistant strains. Also, the bioautography technique allowed visualizing six inhibition halos for the extracts in ethyl acetate from stem bark and three from the leaves, which allows us to conclude that there are at least six plus three active compounds, respectively.

Further experiments aimed at the isolation and structural identification of the active compounds are needed, as well as more pharmacological data to validate the popular use of the extracts from the C. pyramidalis. such as data determining its safety and toxicity.

\section{ACKNOWLEDGEMENTS}

We extend our thanks to Prof. Dr. Agnes M. S. Figueiredo - Laboratory of Molecular Biology of Bacteria, Institute of Microbiology - UFRJ, Rio de Janeiro - RJ, Brazil.

\section{REFERENCES}

ALVES, T.M.A.; SILVA, A.F.; BRANDÃO, M.; GRAND, T.S.M.; SMÂNIA, E.F.A.; SMÂNIA, J.R.A.; ZANI, C.L. Biological screening of brazilian medicinal plants. Mem. Inst. Oswaldo Cruz, v.95, n.3, p.367-373, 2000.

BAHIA, M.V.; DAVID, J.P.; DAVID, J.M. Occurrence of biflavones in leaves of Caesalpinia pyramidalis specimens. Quim. Nova, v.33, n.6, p.1297-300, 2010.

BAHIA, M.V.; SANTOS, J.B.; DAVID, J.P.; DAVID, J.M. Biflavonoids and other phenolics of Caesalpinia pyramidalis (Fabaceae). J. Braz. Chem. Soc., v.16, n.6b, p.1402-1405, 2005.

BRAGA, R. Plantas do nordeste - especialmente do Ceará. 4.ed. Natal: Editora universitária da UFRN,1960. 540 p.

CAETANO, N.; SARAIVA, A.; PEREIRA, R.; CARVALHO, D.; PIMENTEL, M.C.B.; MAIA, M.B.S. Determinação de atividade antimicrobiana de extratos de plantas de uso popular como antiinflamatório. Rev. Bras. Farmacogn., v.12, suppl.1, p.132-135, 2002.

CLINICAL LABORATORY STANDARDS INSTITUTE. CLSI. Performance standards for antimicrobial disk susceptibility tests. Approved standard. 8.ed. Wayne: NCCLS, 2003.58 p. (NCCLS document M2-A8). Available at: <www.sbac.org.br/pt/pdfs/biblioteca/clsi_OPASM7 A6.pdf>. Accessed on: 21 jul. 2011.

CORDEIRO, R.P. Perfil de sensibilidade/resistência de cepas de Staphylococcus aureus. MRSA do Hospital das Clínicas da Universidade Federal de Pernambuco, Recife. Recife, 2004. 55 p. [Dissertation of Master degree in Pharmaceutical Science. Federal University of Pernambuco].

HARBONE J.B. Phytochemical methods. 3.ed. London: Chapman \& Hall, 1998. 320 p.

LENETTE, E.H.; BALOWS, A.; HAUSCLER W.J.; SHADOMY, H.J. Manual de microbiologia clinica. 4.ed. Buenos Aires: Editorial medica panamericana, 1987. 1407 p.

MINISTÉRIO DE MINAS E ENERGIA. MME. Projeto cadastro de fontes de abastecimento por água subterrânea diagnóstico do Município de Carnaubeira da Penha, 2005. 14 p. Available at: <http://www.cprm.gov.br/rehi/atlas/ pernambuco/relatorios/CDPE041.pdf $>$. Accessed on: 22 jun. 2011. 
MARKHAN, K.R. Techniques of flavonoid identification. London: Academic Press, 1982. 113 p.

MENDES, C.C.; BAHIA, M.V.; DAVID, J.M.; DAVID, J.P. Constituents of Caesalpinia pyramidalis. Fitoterapia, v.71, n.2, p.205-207, 2000.

METZ, H. Thin-layer chromatography for rapid assays of enzymatic steroid transformations, Naturwissenschaften, v.48, n.17, p.569-570, 1961.

MIRANDA, O.P.; SILVA-CARVALHO, M.C.; RIBEIRO, A.; PORTELA, F.; CORDEIRO, R.P.; CAETANO, N.; VIDAL, C.F.L.; FIGUEIREDO, A.M.S. Emergency in Brazil of methicillin-resistant Staphylococcus aureus isolates carrying SCCmecIV that realated genetically to the USA800 clone. Clin. Microb. Inf., v.13, p.1165-1172, 2007.

NASCIMENTO, G.G.F.; LOCATELLI, J.; FREITAS, P.C.; SILVA, G.L. Antibacterial activity of plant extracts and phytochemicals on antibiotic-resistant bactéria. Braz. J. Microbiol., v.31, n.4, p.247-256, 2000.

NISHI, H.; KOMATSUWA, H.; FUJIWARA, T.; MCLALLUM, N.; SUGAI, M. Reduced content of lysylphosphatidyglycerol in the cytoplasmic membrane affects susceptibility to moenomycin, as well as vancomycin, gentamicin, and antimicrobial peptides. in Staphylococcus aureus. Antimic. Agents. Chemother., v.48, n.12, p.48004007, 2004.

NOVAIS, T.S.; COSTA, J.F.D.; DAVID, J.P.L.; DAVID, J.M.; QUEIROZ, L.P.; FRANÇA, F.; GIULIETTI, A.M.; SOARES, M.B.P.; SANTOS, R.R.. Atividade antibacteriana em alguns extratos de vegetais do semi-árido brasileiro. Rev. Bras. Farmacogn., v.13, suppl.2, p.5-8, 2003.

OLIVEIRA, G.A.; FARIA, J.B.; LEVY, C.E.; MAMIZUKA, E.M. Characterization of the brazilian endemic clone of methicillin-resistant Staphylococcus aureus (MRSA) from hospitals throughout Brazil. Braz. J. Infect. Dis., v.5, n.4, p.163-170, 2001.

PESSINI, G.L.; HOLETZ, F.D.; SANCHES, N.R.; CORTEZ, D.A.; DIAS FILHO, B.P.; NAKAMURA, C.V. Avaliação da atividade antibacteriana e antifúngica de extratos de plantas utilizadas na medicina popular. Rev. Bras. Farmacogn., v.13, suppl.1, p.21-24, 2003.
RÊGO JÚNIOR, N.O.; FERNANDEZ, L.G.; CASTRO, R.D.; SILVA, L.C.; GUALBERTO, S.A.; PEREIRA, M.L.A.; SILVA, M.V. Bioactive compounds and antioxidant activity of crude extracts of brushwood vegetable species. Braz. J. Food Technol., v.14, n.1, p.50-57, 2011.

ROBERTSON, E.A.H.; CARTWRIGHT, R.A.; OLDSCHOOL, M.M. Phenolic substances of manufactured tea. I. Fractionation and paper chromatography of water-soluble substances. J. Sci. Food Agr., v.8, n.2, p.72-80, 1957.

RODRÍGUEZ-NORIEGA, E.; SEAS, C. The changing pattern of methicillin-resistant Staphylococcus aureus clones in Latin America: implications for clinical practice in the region. Braz. J. Infect. Dis., v.14, supl.2, p.87-96, 2010.

SAKAGAMI, Y.; LINUMA, M.; PIYASEMA, K.G.N.P.; DHARMARATNE, H.R.W. Antibacterial activity of $\alpha$-mangostin agins vancomycin resistant Enterococci (VRE) and synergism with antibiotics. Phytomedicine, v.2, n.3, p.203-208, 2005.

SHIBATA, H.; KONDOK, K.; KATSUYAMA, R.; KAWAZOE, K.; SATO, Y.; MURAKAM, K.; TAKAISHI, Y.; ARAKAKI, N.; HIGUTI, T. Alkyl gallates, intensiefiers of $\beta$-lactam susceptibility in methicillin-resistant Staphylococcus aureus. Antimicrob. Agents Chemother., v.49, n.2, p.549$555,2005$.

SOLA, C.; GRIBAUDO, G.; VINDEL, A.; PATRITO, L.; BOCCO, J.L. Identification of a novel methicillin-resistant Staphylococcus aureus Epidemic Clone in Córdoba, Argentina, Involved in Nosocomial Infections. J. Clin. Microbiol., v.40, n.4, p.1427-1435, 2002.

VORAVUTHIKUNCHAI, S.P.; KITPPIPIT, L . Activity of medicinal plant extracts against hospital isolates of methicillin-resistant Staphylcoccus aureus. Clin. Microbiol. Infect., v.11, n.5, p.493-512, 2005.

WAGNER, H.; BLADT, S.; ZGAINSKI, E.M. Drogenanalyse. Berlin: Springer, Verlag, 1984. 321 p.

WAGNER, H.; BLADT, S. Plant drug analysis - A thin layer chromatography atlas. 2.ed. Munich: Springer. 1996.384 p.

Received for publication on $06^{\text {th }}$ July 2011 Accepted for publication on $17^{\text {th }}$ November 2011 